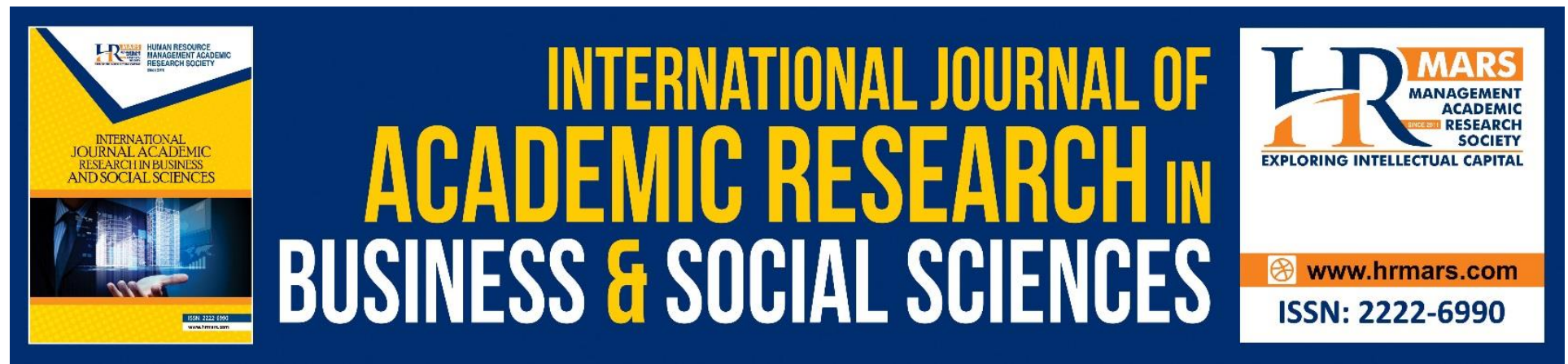

\title{
Differences in the Spoken Discourse Produced by the Autism Spectrum Disorder (ASD) Children
}

Suraya Amirrudin

To Link this Article: http://dx.doi.org/10.6007/IJARBSS/v11-i4/8625

DOI:10.6007/IJARBSS/v11-i4/8625

Received: 17 February 2021, Revised: 20 March 2021, Accepted: 10 April 2021

Published Online: 25 April 2021

In-Text Citation: (Amirrudin, 2021)

To Cite this Article: Amirrudin, S. (2021). Differences in the Spoken Discourse Produced by the Autism Spectrum Disorder (ASD) Children. International Journal of Academic Research in Business and Social Sciences, 11(4), 915-930.

\section{Copyright: (c) 2021 The Author(s)}

Published by Human Resource Management Academic Research Society (www.hrmars.com)

This article is published under the Creative Commons Attribution (CC BY 4.0) license. Anyone may reproduce, distribute, translate and create derivative works of this article (for both commercial and non-commercial purposes), subject to full attribution to the original publication and authors. The full terms of this license may be seen at: http://creativecommons.org/licences/by/4.0/legalcode

Vol. 11, No. 4, 2021, Pg. 915 - 930

Full Terms \& Conditions of access and use can be found at http://hrmars.com/index.php/pages/detail/publication-ethics 


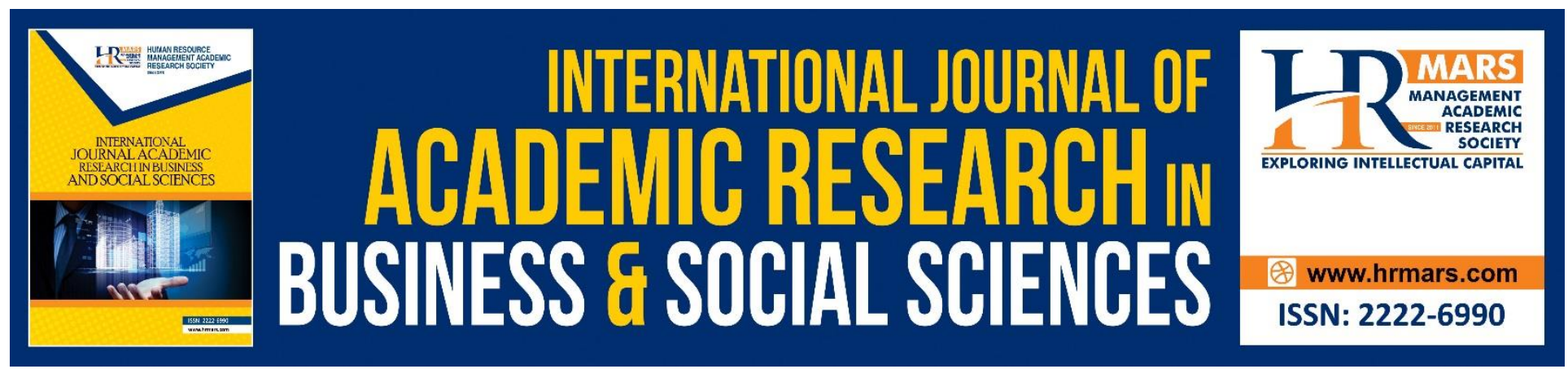

\title{
Differences in the Spoken Discourse Produced by the Autism Spectrum Disorder (ASD) Children
}

\author{
Suraya Amirrudin \\ Infrastructure University Kuala Lumpur
}

\begin{abstract}
Discourse is a social boundary that defines what statements can be said about a topic and discourse among special needs children is different. Additionally, social stories have been described as practical in educational practice and intervention. Therefore, the current research is trying to perceive the functional deficits of the ASD children by acknowledging the possibility of their autistic strengths. Likewise, the leap of research in the field of autism is enormous, and it is said to have increased dramatically in recent years. The current study uses qualitative data to provide details to the research objective; to compare the communicative intent of the spoken discourses produced by the low, medium and high functioning ASD children.There are four female and nine male ASD children selected as the sample for the study. The age is ranged from 9 to 11 years old. As for the instruments, the study utilises two main instruments; social stories and semi-structured interview questions. Nevertheless, to explain more about this phenomenon, the current research uses the Discourse Analysis Theory (Normaliza Abd Rahim, 2019). In the end, the current study is also succeeded in comparing the discourses of the ASD children according to their categories; LFA, MFA and HFA and coming up with the repertoire (list of utterances and gestures). For the communicative intent, two similarities are found; firstly, all the three groups; LFA, MFA and HFA demonstrate the seven communicative intent signals and secondly, their utterances match with the elements in the Discourse Analysis Theory (2019).
\end{abstract}

Keywords: Spoken Discourse, Autism Spectrum Disorder (ASD), Social Stories, Communicative Intent, Discourse Analysis Theory

\section{Introduction}

ASD is a disorder that comes under behaviour, communication and interaction difficulties. Autism was first found by a psychiatrist, Dr. Leo Kanner, who worked at John Hopkins University in 1943. He emphasised that the main effect of autism was the disorder in relationship development with other people (autistic aloofness). Kanner (1943) was also the first person to explain autism at an early stage. In the same year when Kanner (1943) found autism, Dr. Hans Asperger, a German scientist, documented the Asperger syndrome. Only in the 1990s, Asperger syndrome was put in the autism spectrum. However, these two disorders are different accordingly. Children with Asperger syndrome have normal development of communication and motor skills, and its 
obvious symptom is social disorder. In 2013, the DSM-5 replaced Autistic Disorder, Asperger's Disorder and other pervasive developmental disorders with the umbrella diagnosis of autism spectrum disorder.

Furthermore, according to Kanner (1943), not all individuals with autism display withdrawn social behaviour. Knutsen (2013) also found that the ability of children with ASD to communicate and use language depends on their intellectual and social development. Some children with ASD may not be able to communicate using speech or language, and some may have minimal speaking skills. Others may have rich vocabularies and be able to talk about specific subjects in great detail. Some high functioning ASD children could produce echolalia. Echolalia is one of the language characteristics of autism that has been demonstrated to serve communication and social functions (Prizant \& Rydell, 1984). Su, Naigles \& Su (2018) also mentioned about the uneven language development among the three distinct subgroups (high verbal, middle verbal, low verbal) of (Mandarin spoken) ASD children. Since the current study also witnessed the uneven language development among the ASD children, the spoken discourses of the low, medium and high functioning ASD children were analysed and compared for their communicative intent and communicative strategies.

\section{Literature Review}

According to Prizant and Wetherby (1986), communicative intent is the skill to use expressive gestures to affect the behaviour or attitudes of others. Besides that, communicative intent is also connected to social relatedness, social cognition, and communicative knowledge. In the understanding of language and social impairment of the ASD children studies like Johnston et al., (2019); Loytomaki et al., (2019); Suraya \& Normaliza (2019) mentioned about the absence of executive function (EF), and Theory of Mind (ToM) caused the ASD children to manifest the unconventional communicative means. Hence, with functional discrepancies, children with autism often face difficulty in demonstrating communicative intent.

Several studies investigating communicative intent in spoken discourse have been carried out on language and communication. Human language is indeed rich and complex, and the most challenging part is to attend to it and to reminisce everything that it communicates. Luckily, according to Givon (1992), language contains many cues that could provide information about what to attend to and what to remember later. In other words, it means that the ability to use spoken language effectively demands the communicative intent skill in both verbal and nonverbal language, which includes the comprehension and use of a communication symbol system. With this note and since ASD children are low and minimally verbal and some are even non-verbal and produce notably disfluent speech, there have been many studies conducted to look at communicative intent of the spoken discourse among autism. First was Belmonte et al., (2013) examined 31 ASD children to look at their developmental motor speech disorder by using special instruments. They managed to determine children who experienced difficulty in expressive language and those who were suffering from oral motor functioning impairment. These children were seen as having severe injuries in different areas with one and another, and because of that, their expressive language and oral motor skills were passable with their abilities. Besides that, Chenausky et al. (2019) investigated the extent of motor speech impairment from 54 low-verbal 
and minimally verbal ASD children. They found that there was a need to develop spoken language interventions to cater especially the minimally verbal individuals with autism. Other than that, technology is embedded in the intervention to gauge the communicative intent of the autism too like in Wendt et al., (2019) when they used iPad-based Speech Generating Device Infused into instruction together with Picture Exchange Communication System (PECS) to help the young adults with severe autism to be able to depict the request behaviour. This study was also to highlight the communicative intent of the ASD children could be gauged in different ways.

Hengst (2020) in her book "Understanding Everyday Communicative Interactions" stated that interactions are often described as the basic ground for human society and have served as a basic model for understanding other types of communications. In particular, she said discourse analysis examines how people navigate every communicative interaction in real-time. Desiree Kaur et al. (2019) employed a case study design to observe levels of musical engagement for a group of ASD children, and they used the Sounds of Intent (Sol) Framework to see the effects of it. The results showed that the Sol Framework could create an avenue for the integration of music as the classroom activities for children with autism. Cerbo \& Rabi (2019) said that children with autism, unlike their typically developing peers, do not follow all the milestones of development as regards growth and maturation. Specific to this is their delay in the social and communication aspects. Social and communication skills difficulties adversely affect the learning process of learners with ASD. It is recommended that suitable interference is needed to be conducted to address their complications.

In conclusion, with a good medium and intervention platform, communicative intent displayed by the ASD children could be observed. Joining the bandwagon, the current study was using Normaliza (2019) Discourse Analysis Theory to analyse the communicative intent displayed by the ASD children in the study and later the spoken discourses were compared.

\section{Methodology}

Referring to the research objective, the current study was required to have the qualitative data to provide the details. To date, various methods have been developed and introduced to measure the autism phenomenon. A case study design was chosen to allow for a closer approach of the ASD children. 13 ASD children were chosen with reference to the criteria provided by the DSM5. There were only ASD students who were labelled as Level 1 and Level 2 were taken as the sample, whereas the Level 3 ASD students would likely need more intensive, long-term treatment. After a thorough discussion with a clinical psychiatrist and taken into consideration the objective of the study, ASD students who were labelled as Level 3 were excluded from the study. Therefore, only 13 with nine male and four female ASD students were selected.

Since this study was the continuation of a long study, it took the same instruments; social stories and interview questions. Not only that, the same titles of the social stories were used; (Visit atuk and nenek in kampung, Being kind to animals and Helping my family). After presenting the information about the communicative intent among the ASD children, the data were further compared according to the levels of the ASD respondents; low-functioning, medium-functioning and high-functioning. The comparison was clearly based on the elements inside the theoretical 
frameworks. From the transcriptions, data were analysed by using the theories and presented in the following chapter.

Theoretical Framework

\begin{tabular}{lll}
\hline Discourse Analysis Theory (Normaliza Abd Rahim, 2019) & \\
\hline Content & Context & Assumption \\
1. Theme & 1. Grammar & 1. Opinion \\
& 2. Setting & 2. Reference \\
& 3. Emotion & 3. Question \\
\end{tabular}

Table 2: Discourse Analysis Theory (DAT)

The above Table 2 displays details of DAT. Referring to Normaliza (2019), the first element of DAT is the content, and this element is analysed through a theme that could be captured from materials like books, texts or even utterances. The theme is the subject that becomes the fundamental of a text, writing, utterances or interaction. The theme can also be the main idea for the discussion. As for the context, it has three sub-elements; grammar, setting and emotion. Grammar focusses on the syntactical and morphological constituent of the words, phrases and sentences. On the other hand, the setting is analysed following the information about location, time and people. As for the emotion, it is analysed when reactions and feelings are shown as the reflection towards a situation. Finally is the assumption. Normaliza (2019) also emphasises that assumption has three sub-headings; opinion, references and question. Primarily, opinion is deliberated from all the sources that surround the discourse, which is the text, utterances and interaction. Reference, on the other hand, is seen as the opportunity that the speaker or writer could have in recalling and bringing in any ideas referring to the matter that is being discussed and lastly is questioned. This sub-element is seen as necessary because according to the theorist, it is the nature of the speaker or writer to ask questions for clarification and confirmation on certain things. 
INTERNATIONAL JOURNAL OF ACADEMIC RESEARCH IN BUSINESS AND SOCIAL SCIENCES

Vol. 11, No. 4, 2021, E-ISSN: $2222-6990$ @ 2021 HRMARS

Results and Discussion

Comparison of the communicative intent of the spoken discourses produced by the low, medium and high functioning ASD children

\begin{tabular}{|c|c|c|c|c|c|c|}
\hline \multirow{2}{*}{$\begin{array}{l}\text { Discourse } \\
\text { Analysis Theory } \\
\text { (2019) }\end{array}$} & \multicolumn{2}{|c|}{ LFA } & \multicolumn{2}{|c|}{ MFA } & \multicolumn{2}{|c|}{ HFA } \\
\hline & Utterances & $\begin{array}{c}\text { Communicative } \\
\text { Intent }\end{array}$ & Utterances & $\begin{array}{c}\text { Communicative } \\
\text { Intent }\end{array}$ & Utterances & $\begin{array}{c}\text { Communicative } \\
\text { Intent }\end{array}$ \\
\hline $\begin{array}{l}\text { Content } \\
\text { Theme }\end{array}$ & $\begin{array}{l}\text { LT1. Love } \\
\text { LT2. Peluk atuk } \\
\text { nenek } \\
\text { (hug atuk and } \\
\text { nenek) } \\
\text { LT3. Peluk la } \\
\text { (hug) } \\
\text { LT4. Sayang } \\
\text { LT5. Peluk atuk, } \\
\text { peluk nenek (hug } \\
\text { atuk, hug nenek) } \\
\text { LT6. No } \\
\text { LT7. Makan } \\
\text { kucing } \\
\text { (cat eats) } \\
\text { LT8. Tahu } \\
\text { LT9. Kasi makan } \\
\text { kasi minum air } \\
\text { (give animals }\end{array}$ & $\begin{array}{l}\text { - Communicat } \\
\text { ion display } \\
\text { - Intention of } \\
\text { uttering } \\
\text { words: } \\
\text { the words uttered } \\
\text { were minimal and } \\
\text { many of them were } \\
\text { single words and } \\
\text { short phrases. }\end{array}$ & $\begin{array}{l}\text { MT1. Cium tangan } \\
\text { atuk dan nenek } \\
\text { (kiss atuk and } \\
\text { nenek's hands) } \\
\text { MT2. Saya cakap I } \\
\text { love you } \\
\text { (I tell them I love } \\
\text { you) } \\
\text { MT3. Hug them } \\
\text { MT4. Ye tahu } \\
\text { (Yes I know) } \\
\text { MT5. Kindness...kuc } \\
\text { ing makan nasi } \\
\text { dengan ikan } \\
\text { (cat eats rice with } \\
\text { fish) } \\
\text { MT6. Saya ada } \\
\text { kucing aje cikgu. } \\
\text { Saya sayang la... }\end{array}$ & $\begin{array}{l}\text { - Communicat } \\
\text { ion display } \\
\text { - Intention of } \\
\text { uttering } \\
\text { words: } \\
\text { the words uttered } \\
\text { were more than the } \\
\text { LFA and many of } \\
\text { them were single } \\
\text { short phrases. }\end{array}$ & $\begin{array}{l}\text { HT1. Yes...Love } \\
\text { sangat } \\
\text { (love them so } \\
\text { much) } \\
\text { HT2. Saya peluk } \\
\text { atuk, cikgu...peluk } \\
\text { nenek juga. (I hug } \\
\text { my atuk and } \\
\text { nenek, teacher) } \\
\text { HT3. Yes, love } \\
\text { HT4. Say I love } \\
\text { you, cium, pegang } \\
\text { tangan...buat } \\
\text { macam ni... } \\
\text { (I say I love you, I } \\
\text { kiss and hold their } \\
\text { hands. I do like } \\
\text { this...) }\end{array}$ & $\begin{array}{l}\text { Generative } \\
\text { language } \\
\text { Communicat } \\
\text { ion display } \\
\text { (pronunciati } \\
\text { on was clear) } \\
\text { - Intention of } \\
\text { uttering } \\
\text { words: } \\
\text { the words uttered } \\
\text { were more than LFA } \\
\text { and MFA and many } \\
\text { of them were long } \\
\text { phrases and clauses. }\end{array}$ \\
\hline
\end{tabular}


INTERNATIONAL JOURNAL OF ACADEMIC RESEARCH IN BUSINESS AND SOCIAL SCIENCES

Vol. 11, No. 4, 2021, E-ISSN: 2222-6990 @ 2021 HRMARS

\begin{tabular}{|c|c|c|c|c|c|c|}
\hline & $\begin{array}{l}\text { food to eat and } \\
\text { water to drink) } \\
\text { LT10. Tolong ayah } \\
\text { (I help my father) } \\
\text { LT15. Tolong } \\
\text { basuh pinggan } \\
\text { (helping washing } \\
\text { the plates) }\end{array}$ & & $\begin{array}{l}\text { (I only have cats } \\
\text { teacher and I love } \\
\text { them.) }\end{array}$ & & $\begin{array}{l}\text { HT5. Yes, I love } \\
\text { tokma so much. } \\
\text { (tokma=nenek) } \\
\text { HT6. Normally, I } \\
\text { kiss her hands and } \\
\text { she kiss me back. } \\
\text { HT7. Yes } \\
\text { cikgu...saya love } \\
\text { atuk nenek saya. } \\
\text { (Yes teacher, I love } \\
\text { my atuk and } \\
\text { nenek) }\end{array}$ & \\
\hline $\begin{array}{l}\text { Context } \\
\text { Grammar }\end{array}$ & $\begin{array}{l}\text { LG1. Sedih (sad) } \\
\text { LG2. Nangis (cry) } \\
\text { LG3. Hadiah } \\
\text { (present) } \\
\text { LG4.Marah...sedih } \\
\text { (angry...sad) } \\
\text { LG5. } \\
\text { Hadiah...suka } \\
\text { (present...happy) } \\
\text { LG6. Haiwan mati } \\
\text { (animal will die) } \\
\text { LG7. Krishnan } \\
\text { happy }\end{array}$ & $\begin{array}{l}\text { Demonstrated a lot } \\
\text { of ritualisation of } \\
\text { signals within the } \\
\text { contexts. } \\
\text { Very minimal ability } \\
\text { in understanding } \\
\text { the grammar } \\
\text { elements } \\
\text { Overall, didn't } \\
\text { manage to pull } \\
\text { together intention, } \\
\text { means of } \\
\text { communication and } \\
\text { function of the }\end{array}$ & $\begin{array}{l}\text { MG1. Sad...cry } \\
\text { MG2. Happy } \\
\text { Jump...jump...yeah } \\
\text { MG3. Saya tak } \\
\text { tahu...saya nangis (I } \\
\text { don't know...I cry). } \\
\text { MG4. Hadiah? Saya } \\
\text { happy teacher } \\
\text { (Present?) (I'm } \\
\text { happy, teacher) } \\
\text { MG5. I like present. } \\
\text { Happy } \\
\text { MG6. Main dengan } \\
\text { ayam, lembu (play }\end{array}$ & $\begin{array}{l}\text { Demonstrated } \\
\text { minimal ritualisation } \\
\text { of signals within the } \\
\text { contexts. } \\
\text { Ability in } \\
\text { understanding the } \\
\text { elements grammar } \\
\text { was apparent from } \\
\text { the utterances. } \\
\text { Overall, managed to } \\
\text { pull together } \\
\text { intention, means of } \\
\text { communication and } \\
\text { function of the }\end{array}$ & $\begin{array}{l}\text { HG1. Wendy } \\
\text { sedih...saya pun } \\
\text { kena marah } \\
\text { (Wendy is sad...I'm } \\
\text { being scolded too) } \\
\text { HG2. Sad teacher } \\
\text { HG3. Happy la } \\
\text { HG4. I want } \\
\text { present too. } \\
\text { Wendy sedih } \\
\text { sebab tu dia kasi } \\
\text { animals dia } \\
\text { makan. }\end{array}$ & $\begin{array}{l}\text { Demonstrated very } \\
\text { minimal ritualisation } \\
\text { of signals within the } \\
\text { contexts. } \\
\text { Ability in } \\
\text { understanding the } \\
\text { elements grammar } \\
\text { was apparent from } \\
\text { the utterances. } \\
\text { Overall, managed } \\
\text { to pull together } \\
\text { intention, means of } \\
\text { communication and } \\
\text { function of the }\end{array}$ \\
\hline
\end{tabular}


INTERNATIONAL JOURNAL OF ACADEMIC RESEARCH IN BUSINESS AND SOCIAL SCIENCES Vol. 11, No. 4, 2021, E-ISSN: 2222-6990 @ 2021 HRMARS

\begin{tabular}{|c|c|c|c|c|c|c|}
\hline & $\begin{array}{l}\text { LG8. Jumpa atuk } \\
\text { dan nenek (visit } \\
\text { atuk and nenek) } \\
\text { LG9. Mandi } \\
\text { sungai (swim in } \\
\text { the river) }\end{array}$ & $\begin{array}{l}\text { message within the } \\
\text { context. }\end{array}$ & $\begin{array}{l}\text { with chickens and } \\
\text { cows) }\end{array}$ & $\begin{array}{l}\text { message within the } \\
\text { context. }\end{array}$ & $\begin{array}{l}\text { (Wendy is sad } \\
\text { that's why she } \\
\text { feeds the animals) } \\
\text { HG5. Ayah Aliff } \\
\text { bawa kereta } \\
\text { (Aliff's father } \\
\text { drives the car) }\end{array}$ & $\begin{array}{l}\text { message within the } \\
\text { context. }\end{array}$ \\
\hline $\begin{array}{l}\text { Setting } \\
\text { Location } \\
\\
\text { Time }\end{array}$ & $\begin{array}{l}\text { LL1. Aliff } \\
\text { kampung (Aliff is } \\
\text { in kampung) } \\
\text { LL2. Wendy main } \\
\text { dengan animals } \\
\text { (Wendy is playing } \\
\text { with the animals) } \\
\text { LL3. Kampung } \\
\text { LL4. Rumah (at } \\
\text { home) } \\
\text { LTi1. } \\
\text { Kampung...rumah } \\
\text { nenek (at nenek's } \\
\text { house) } \\
\text { LTi2. River } \\
\text { LTi3. Pagi } \\
\text { (morning) } \\
\text { LTi4. Saya mandi } \\
\text { pagi (I bathe in } \\
\text { the morning) }\end{array}$ & $\begin{array}{l}\text { Echolalia } \\
\text { Two (R4 and R5) } \\
\text { from LFA had their } \\
\text { echolalia }\end{array}$ & $\begin{array}{l}\text { ML1. Wendy kat } \\
\text { rumah (Wendy is at } \\
\text { home) } \\
\text { ML2. Krishnan pun } \\
\text { kat rumah. } \\
\text { (Krishnan is at } \\
\text { home too) } \\
\text { ML3. Semua kat } \\
\text { rumah mereka (All } \\
\text { are at home) } \\
\text { MTi1. Kampung } \\
\text { and house Petang } \\
\text { dan malam } \\
\text { (evening and night) } \\
\text { MTi2. Kucing pagi } \\
\text { (cat in the } \\
\text { morning) } \\
\text { MTi3. Anjing dia } \\
\text { mandi petang (dog }\end{array}$ & $\begin{array}{l}\text { Echolalia } \\
\text { Two (R7 and R10) } \\
\text { from MFA had their } \\
\text { echolalia }\end{array}$ & $\begin{array}{l}\text { HL1. Di rumah } \\
\text { mereka (at their } \\
\text { house) } \\
\text { hL2. Aliff is in } \\
\text { kampung and at } \\
\text { the river. } \\
\text { HL3. Wendy's } \\
\text { animals are at } \\
\text { home. } \\
\text { HL4. Krishnan and } \\
\text { his family are } \\
\text { staying at home } \\
\text { HL5. Wendy kat } \\
\text { rumah (Wendy is } \\
\text { at home) } \\
\text { HL6. Krishnan pun } \\
\text { kat rumah. } \\
\text { (Krishnan is at } \\
\text { home too) }\end{array}$ & $\begin{array}{l}\text { Echolalia } \\
\text { One (R13) from HFA } \\
\text { had his echolalia. }\end{array}$ \\
\hline
\end{tabular}


INTERNATIONAL JOURNAL OF ACADEMIC RESEARCH IN BUSINESS AND SOCIAL SCIENCES

Vol. 11, No. 4, 2021, E-ISSN: 2222-6990 @ 2021 HRMARS

\begin{tabular}{|c|c|c|c|c|c|c|}
\hline & & & $\begin{array}{l}\text { is having a bath in } \\
\text { the evening) }\end{array}$ & & $\begin{array}{l}\text { HTi1. Kucing hari } \\
\text { Isnin (cat is on } \\
\text { Monday) } \\
\text { HTi2. Anjing hari } \\
\text { Selasa ke cikgu } \\
\text { (dog is on Tuesday } \\
\text { right teacher?) } \\
\text { HTi3. Tengahhari } \\
\text { sebab kalau pagi } \\
\text { sejuk (it's } \\
\text { afternoon, } \\
\text { because if it's in } \\
\text { the morning it's } \\
\text { cold) }\end{array}$ & \\
\hline $\begin{array}{l}\text { Emotion } \\
\text { (utterances+bo } \\
\text { dy language) }\end{array}$ & $\begin{array}{l}\text { No } \\
\text { LE1. Facial } \\
\text { expression } \\
\text { changes-looking } \\
\text { worried } \\
\text { LE2. Shake head } \\
\text { LE3. Eyes were } \\
\text { looking at } \\
\text { somewhere else } \\
\text { LE4. Quiet and } \\
\text { was looking } \\
\text { down } \\
\text { Tidak (No) }\end{array}$ & $\begin{array}{l}\text { Changes in facial } \\
\text { expression as well } \\
\text { as eye gaze were } \\
\text { detected a lot } \\
\text { among LFA }\end{array}$ & $\begin{array}{l}\text { Eggs no...Atuk no } \\
\text { ME1. Shake head } \\
\text { No...cannot } \\
\text { Atuk angry } \\
\text { ME2. Making a } \\
\text { frown face } \\
\text { No... Nanti telur } \\
\text { sikit (Eggs will } \\
\text { become lesser) } \\
\text { Kesian kucing tu } \\
\text { (Pity the cat) } \\
\text { ME3. Looking sad }\end{array}$ & $\begin{array}{l}\text { Changes in facial } \\
\text { expression as well } \\
\text { as eye gaze were } \\
\text { detected lesser than } \\
\text { the LFA } \\
\text { Signals for social } \\
\text { emotion were } \\
\text { visible in the } \\
\text { utterances. }\end{array}$ & $\begin{array}{l}\text { No. Marah atuk } \\
\text { Aliff. (Aliff's atuk } \\
\text { will be angry) } \\
\text { HE1. Shake head } \\
\text { No...cannot } \\
\text { Atuk marah nanti } \\
\text { (Atuk will be angry } \\
\text { later) } \\
\text { HE2. Shake } \\
\text { head...eyes were } \\
\text { looking at R12 } \\
\text { If you ask properly, } \\
\text { you can take it. }\end{array}$ & $\begin{array}{l}\text { Changes in facial } \\
\text { expression as well } \\
\text { as eye gaze were } \\
\text { detected lesser than } \\
\text { the LFA and MFA. } \\
\text { Signals for social } \\
\text { emotion were } \\
\text { visible clearly in the } \\
\text { utterances. }\end{array}$ \\
\hline
\end{tabular}


INTERNATIONAL JOURNAL OF ACADEMIC RESEARCH IN BUSINESS AND SOCIAL SCIENCES Vol. 11, No. 4, 2021, E-ISSN: 2222-6990 @ 2021 HRMARS

\begin{tabular}{|c|c|c|c|c|c|c|}
\hline & $\begin{array}{l}\text { Atuk marah (Atuk } \\
\text { is angry) } \\
\text { Sedih (sad) } \\
\text { LE5. Stare at } \\
\text { researcher } \\
\text { LE6. Eyes were } \\
\text { looking at } \\
\text { somewhere else } \\
\text { Cry }\end{array}$ & & $\begin{array}{l}\text { Saya tak bawa balik } \\
\text { (I won't take them } \\
\text { back home) } \\
\text { ME4. Shake head } \\
\text { and look sad } \\
\text { Sad so I bring home } \\
\text { the baby cat } \\
\text { ME5. Looking } \\
\text { happy } \\
\text { ME6. Smiling }\end{array}$ & & $\begin{array}{l}\text { Cannot steal of } \\
\text { course. Must ask. } \\
\text { HE3. Making a } \\
\text { frown face } \\
\text { No tak boleh, } \\
\text { cikgu. Kena tanya. } \\
\text { Berdosa... } \\
\text { (No, you cannot } \\
\text { teacher. You have } \\
\text { to ask...it's sinful) } \\
\text { HE4. Facial } \\
\text { expression } \\
\text { changes. }\end{array}$ & \\
\hline $\begin{array}{l}\text { Assumption } \\
\text { Opinion }\end{array}$ & $\begin{array}{l}\text { LO1. Boleh (Yes) } \\
\text { LO2. Tak (No) } \\
\text { LO3. Tak tahu (I } \\
\text { don't know) } \\
\text { LO4. Dia...abang } \\
\text { tolong (The } \\
\text { brother is helping } \\
\text { her) } \\
\text { LO5. Dia tak tahu } \\
\text { (She doesn't } \\
\text { know) } \\
\text { LO6. Cikgu... } \\
\text { tolong...aaa...em }\end{array}$ & $\begin{array}{l}\text { Vocalisation was } \\
\text { demonstrated. } \\
\text { Opinions were not } \\
\text { visible. }\end{array}$ & $\begin{array}{l}\text { MO1. Boleh (Yes) } \\
\text { M02. Kerja sekolah } \\
\text { senang } \\
\text { (Homework is easy) } \\
\text { M03. Tanya emak } \\
\text { (Ask the mother) } \\
\text { M04. Sebab dia } \\
\text { kecil lagi (Because } \\
\text { they are still small) } \\
\text { M05. Yes they can } \\
\text { MO6. I don't want } \\
\text { homework }\end{array}$ & $\begin{array}{l}\text { No vocalisation. } \\
\text { Demonstrated } \\
\text { minimal ritualisation } \\
\text { of signals within the } \\
\text { contexts. } \\
\text { Minimal opinions } \\
\text { were heard. }\end{array}$ & $\begin{array}{l}\text { HO1. Boleh cikgu } \\
\text { (Yes they can, } \\
\text { teacher) } \\
\text { HO2. Sebab dia } \\
\text { sekolah (Because } \\
\text { they go to school) } \\
\text { HO3. Tak boleh } \\
\text { (No)...cannot } \\
\text { HO4. Because dia } \\
\text { adik, Krishnan } \\
\text { abang (Because } \\
\text { they are sisters }\end{array}$ & $\begin{array}{l}\text { No vocalisation. } \\
\text { Demonstrated very } \\
\text { minimal ritualisation } \\
\text { of signals within the } \\
\text { contexts. } \\
\text { Opinions were } \\
\text { heard clearly. }\end{array}$ \\
\hline
\end{tabular}


INTERNATIONAL JOURNAL OF ACADEMIC RESEARCH IN BUSINESS AND SOCIAL SCIENCES

Vol. 11, No. 4, 2021, E-ISSN: 2222-6990 @ 2021 HRMARS

\begin{tabular}{|c|c|c|c|c|c|c|}
\hline & $\begin{array}{l}\text { mm (Teacher can } \\
\text { help) }\end{array}$ & & & & $\begin{array}{l}\text { and Krishnan is a } \\
\text { brother) } \\
\text { HO5. Homework is } \\
\text { easy } \\
\text { HO6. Tak boleh } \\
\text { cikgu. (No they } \\
\text { can't, teacher) }\end{array}$ & \\
\hline Reference & $\begin{array}{l}\text { LR1. Tolong ayah } \\
\text { (I help my father) } \\
\text { LR2. Tolong cuci } \\
\text { car...cuci (I help } \\
\text { him with washing } \\
\text { the car) } \\
\text { (hardly made } \\
\text { reference) } \\
\text { LR3. Aliff suka } \\
\text { atuk nenek } \\
\text { LR4. Sedih...cry } \\
\text { (sad) } \\
\text { LR5. Hadiah...suka } \\
\text { (present...happy) } \\
\text { LR6. Boleh (Yes) } \\
\text { LR7. Cik...gu } \\
\text { tolong (Teacher } \\
\text { can help) }\end{array}$ & $\begin{array}{l}\text { Vocalisation } \\
\text { References were } \\
\text { hardly made by one } \\
\text { respondents and } \\
\text { only visible } \\
\text { minimally from } \\
\text { others. }\end{array}$ & $\begin{array}{l}\text { MR1. Saya mandi } \\
\text { pagi (I bathe in the } \\
\text { morning) MR2. } \\
\text { Saya tolong emak, } \\
\text { ayah, semua. (I } \\
\text { help my mother, } \\
\text { father and } \\
\text { everyone) } \\
\text { MR3. Nanti telur } \\
\text { sikit (Eggs will } \\
\text { become lesser) } \\
\text { MR4. I help my } \\
\text { mum with } \\
\text { washing...baju, } \\
\text { pinggan. (clothes } \\
\text { and plates) } \\
\text { MR5. I don't want } \\
\text { homework }\end{array}$ & $\begin{array}{l}\text { No vocalisation. } \\
\text { Demonstrated } \\
\text { minimal ritualisation } \\
\text { of signals within the } \\
\text { contexts. } \\
\text { Minimal references } \\
\text { were heard. }\end{array}$ & $\begin{array}{l}\text { HR1. Saya tolong } \\
\text { ayah cuci kereta. (I } \\
\text { help my father } \\
\text { washing his cars) } \\
\text { HR2. Boleh cikgu } \\
\text { (Yes they can, } \\
\text { teacher) } \\
\text { HR3. Sebab dia } \\
\text { sekolah (Because } \\
\text { they go to school) } \\
\text { HR4. Saya tolong } \\
\text { kakak. (I help my } \\
\text { sister) } \\
\text { HR5. Kakak pun } \\
\text { tolong } \\
\text { saya...homework.( } \\
\text { My sister helps me } \\
\text { too with my } \\
\text { homework) }\end{array}$ & $\begin{array}{l}\text { No vocalisation. } \\
\text { Demonstrated } \\
\text { minimal ritualisation } \\
\text { of signals within the } \\
\text { contexts. } \\
\text { References were } \\
\text { heard clearly. }\end{array}$ \\
\hline
\end{tabular}


INTERNATIONAL JOURNAL OF ACADEMIC RESEARCH IN BUSINESS AND SOCIAL SCIENCES

Vol. 11, No. 4, 2021, E-ISSN: 2222-6990 @ 2021 HRMARS

\begin{tabular}{|c|c|c|c|c|c|c|}
\hline & & & & & $\begin{array}{l}\text { HR6. I help Yaya } \\
\text { my sister cleaning } \\
\text { up her toys. }\end{array}$ & \\
\hline Question & $\begin{array}{l}\text { LQ1. Tidak } \\
\text { selamat? (Not } \\
\text { safe?) } \\
\text { LQ2. Mati (Die) } \\
\text { LQ3. Mati ke? } \\
\text { (Die?) } \\
\text { LQ4. Mati ke } \\
\text { teacher? (Did } \\
\text { they die teacher?) } \\
\text { LQ5. Saya tak } \\
\text { tahu. (I don't } \\
\text { know) } \\
\text { LQ6. Mati kot } \\
\text { (Die, I think) }\end{array}$ & $\begin{array}{l}\text { Minimal awaiting } \\
\text { response from the } \\
\text { LFA respondents } \\
\text { was observed } \\
\text { Questioning ability } \\
\text { was very minimal } \\
\text { too. }\end{array}$ & $\begin{array}{l}\text { MQ1. Cikgu rasa, } \\
\text { mati ke kucing tu? } \\
\text { (Do you think they } \\
\text { will die, teacher?) } \\
\text { MQ2. Wendy } \\
\text { biarkan? (Did } \\
\text { Wendy leave } \\
\text { them?) } \\
\text { MQ3. Ye ke? Tak } \\
\text { kot. (Is it? I don't } \\
\text { think so) } \\
\text { Selamat saya rasa. } \\
\text { (I think they are } \\
\text { safe) } \\
\text { MQ4. People come } \\
\text { and save } \\
\text { them...kan } \\
\text { teacher? (right, } \\
\text { teacher) }\end{array}$ & $\begin{array}{l}\text { Awaiting response } \\
\text { from the MFA } \\
\text { respondents was } \\
\text { good. } \\
\text { Questioning ability } \\
\text { was apparent and } \\
\text { could be observed } \\
\text { clearly too. }\end{array}$ & $\begin{array}{l}\text { HQ1. Die? } \\
\text { HQ2. Tak la...dia } \\
\text { cari makan lain. (I } \\
\text { don't think so. } \\
\text { They somewhere } \\
\text { else to find their } \\
\text { food) } \\
\text { HQ3. Orang lain } \\
\text { datang. (Other } \\
\text { people will come) } \\
\text { HQ4. Betul tak } \\
\text { teacher? (Isn't it } \\
\text { teacher) } \\
\text { HQ5. Yes they will. } \\
\text { HQ6. Why Wendy } \\
\text { did not want to } \\
\text { save them? }\end{array}$ & $\begin{array}{l}\text { Awaiting response } \\
\text { from the HFA } \\
\text { respondents was } \\
\text { good. } \\
\text { Questioning ability } \\
\text { was demonstrated } \\
\text { clearly too. }\end{array}$ \\
\hline
\end{tabular}


Only the HFA respondents (HT1-HT13) demonstrated generative language ability where the number of words that they uttered were more than the LFA and MFA, and many of the utterances were long phrases and clauses; for examples, "Saya peluk atuk, cikgu...peluk nenek juga", "Say I love you, cium, pegang tangan...buat macam ni..." and "Saya kasi animals makan cat food dan minum air". On the contrary, the LFA respondents only demonstrated communication display and intention of uttering words. Apart from that, the words uttered were minimal and many of them were single words and short phrases (LT1-LT15 e.g. "Love", "Peluk atuk nenek", "sayang", "kasi makan"). As for the MFA, the number of short phrases produced by them were more (MT1-MT11); for examples, "Cium tangan atuk dan nenek", "Saya tolong adik", "Tolong semua cikgu".

The second communicative intent observed was the ability in ritualising the form of signal within the contexts. This element of communicative intent happened when the ASD respondents had difficulties and they found it challenging to respond to the situations or questions during the sessions. For this communicative intent, during the 'grammar session', the LFA respondents demonstrated a lot of ritualisation of signals within the contexts; for examples (LG1-LG13), "Sedih", "Nangis", "Marah...sedih" and "Aliff makan" and did not managed to pull together the intention, means of communication and function of the message within the context. As for the MFA respondents, they demonstrated minimal ritualisation of signals within the contexts because they managed to pull together intention, means of communication and function of the message within the context; for examples (MG1-MG11), "Saya tak tahu...saya nangis", "Hadiah? Saya happy teacher", and "Aliff main dengan lembu kambing". Finally, the HFA demonstrated very minimal ritualisation of signals within the contexts and overall, they managed to pull together intention, means of communication and function of the message within the context and as a result, they produced better utterances (HG1HG7); for examples, "Wendy sedih...saya pun kena marah", "I want present too. Wendy sedih sebab tu dia kasi animals dia makan" and "Aliff swims in the river. He eats food with family and he feeds animals too".

This communicative intent element was seen again during the 'opinion session' and 'reference session'. Since the LFA respondents found the questions posed to them challenging and they could not respond exactly to the questions, they demonstrated the vocalisation element. They produced unintelligible speech; for examples (LO1-LO6), "Dia...abang tolong", Cikgu... tolong...aaa...emmm" and, and (LR1-LR7), "Tolong cuci car...cuci", "Hadiah...suka" and "Cik...gu tolong". Furthermore, there was vocalisation and minimal ritualisation of signals within the contexts that was demonstrated by the MFA and LFA respondents. Utterances produced by the MFA (MO1-MO6 and MR1-MR5) were more sensible; for examples, "Kerja sekolah senang", "Sebab dia kecil lagi", "I don't want homework" and "Saya tolong emak, ayah, semua", and the HFA respondents also produced clear utterances (HO1-HO7) and (HR1HR7); for examples, "Because dia adik, Krishnan abang", "Homework is easy.", "Saya tolong ayah cuci kereta." and "Kakak pun tolong saya...homework".

Correspondingly, the next communicative intent observed was echolalia, and echolalia occurred in the respondents' utterances. Two (R4 and R5) from LFA, two (R7 and R10) from MFA and one (R13) from HFA respondents had echolalia in their utterances. The echolalia produced by these respondents were immediate echolalia where most of the time they were echoing their friends' answers; for examples, "Kampung...rumah nenek" and "Pagi", "Saya 
mandi pagi", "Krishnan pun kat rumah" (ML2 and ML6) and "Wendy kat rumah" (HL1 and $\mathrm{HL5}$ ) or they responded by repeating the words or phrases from the questions posed to them; "River", "Kucing pagi" and "Kucing hari Isnin".

Furthermore, the ASD respondents demonstrated another communicative intent which was alternating eye gaze, persistent signalling and body language. For this, the LFA displayed a lot of changes in facial expression as well as eye gaze during the sessions; for examples (LE1-LE9) - changes in facial expression included looking worried, shaking of the head, looking elsewhere, and staring at the researcher. In contrast, changes in facial expression as well as eye gaze were lesser in MFA (ME1-ME6) and HFA (HE1-HE6) respondents.

Finally, the ASD respondents from the three groups were also observed in terms of their awaiting response from the listener and ability to question. Observations showed minimal awaiting response and minimal ability to question by the LFA respondents. The LFA respondents did not modify the form of a signal or use an alternative strategy (LQ1-LQ6); for example, "Saya tak tahu", "Mati" and "Mati kot", and as for their minimal questioning ability, they only asked simple questions: "Tidak selamat" and "Mati ke teacher?". On the other hand, the MFA respondents demonstrated good awaiting response ability and their questioning ability was apparent and could be observed clearly, too; for examples (MQ1-MQ4), "Ye ke? Tak kot", "Cikgu rasa, mati ke kucing tu?" and "People come and save them...kan teacher?". Similarly, the HFA respondents demonstrated good awaiting response where they managed to modify the form of a signal or use an alternative strategy like reasoning; for examples (HQ1HQ8), "Tak la...dia cari makan lain" and "Mati la...sebab terbiar" as for their questioning ability, they could come up with these questions such as "Why Wendy did not want to save them?" and "Takkan orang lain tak nampak cikgu?".

\section{Conclusion}

In conclusion, two similarities were found; firstly, all the three groups; LFA, MFA and HFA demonstrated the seven communicative intent signals and secondly, their utterances matched with the elements in DAT (2019). On the other hand, among the differences were the length of the utterances produced by the LFA, MFA and HFA respondents and the echolalia and also the gestures that they exhibited. Moving on to the communicative strategies, all strategies were engaged by the 13 ASD respondents and they were different in terms of the degree on how much the engagement was.

Subsequently, the current study was succeeded in coming up with the repertoire (utterances and gestures) from the ASD children presented in tables of the comparison of the communicative intent and communicative strategies. Overall, in terms of the communicative intent, the LFA respondents did not demonstrate the generative language ability instead they showed of the vocalisation ability. This was seen from the utterances that they produced; they were only simple words and if they came up with longer phrases or clauses, they became unintelligible. Furthermore, having the MFA respondents in the study, we could see big differences between the HFA and the LFA. MFA respondents was observed as not having the generative language ability but they could utter more words and phrases and they did have a little vocalisation in their utterances sometimes. In comparison to the LFA, the MFA's utterances were more senseful. Echolalia, alternating eye gaze and body language were also realised in them. In comparison to the HFA, changes in facial expression as well as eye gaze 
were detected lesser in the MFA. Finally, the MFA respondents demonstrated good awaiting response ability and their questioning ability was apparent and could be observed clearly too.

\section{References}

Alias, A. (2013). The issues in implementing transition program for special needs students. Journal of Special Education. 9 (16):9-14. Canadian Center of Science and Education.

Asperger, H. (1991). Autistic psychopathy in childhood. In Frith, Uta (ed.), Autism and Asperger Syndrome. Cambridge: Cambridge University Press, 1991: 37-92.

Belmonte, M., Saxena-Chandhok, T., Cherian, R., Muneer, R., George, L. \& Karanth, P. (2013). Oral motor deficits in speech-impaired children with autism. Front. Integr. Neurosci https://doi.org/10.3389/fnint.2013.00047

Cerbo, S. N., \& Rabi, N. M. (2019). The social and communication skills difficulties among Learners with Autism Spectrum Disorder. International Journal of Academic Research in Business and Social Sciences, 9(6), 1152-1162.

Chenausky, K., Brignell, A., Morgan, A., \& Tager-Flusberg, H. (2019). Motor speech impairment predicts expressive language in minimally verbal, but not low verbal, individuals with autism spectrum disorder. Autism \& Developmental Language Impairments. Volume 4: 1-12

Givón, T. (1992). The grammar of referential coherence as mental processing instructions. Linguistics, 30, 5-56. https://doi.org/10.1515/ ling.1992.30.1.5

Hengst, J. A. (2020). Understanding everyday communication interactions. Taylor \& Francis. Published by Routledge

Johnston, K., Murray, K., Spain, D., Walker, I., \& Russell, A. (2019). Executive function: Cognition and behaviour in adults with Autism Spectrum Disorders (ASD). Journal of Autism and Developmental Disorders.

Kanner, L. (1943). Autistic disturbances of affective contact. Nervous Child: Journal of Psychopathology, Psychotherapy, Mental Hygiene, and Guidance of the Child 2: 217-50.

Knutsen, J. (2013). The understanding of teaching in children with Autism Spectrum Disorder. University of Pennsylvania.

Loytomaki, J., Ohtonen, P., Laakso, M. L., \& Huttunen, K. (2019). The role of linguistic and cognitive factors in emotion recognition difficulties in children with ASD, ADHD or DLD. International Journal of Language and Communication Disorders. Vol. 00, NO. 0, 1-12

Abd Rahim, N. (2019). Kajian wacana dan strategi komunikasi. Teori dan Aplikasi. Penerbit UMT Universiti Malaysia Terengganu

Prizant, B. M. (1984), Echolalia in autism: assessment and intervention. Semin. Speech Lang, 4:63-78.

Prizant, B. M., \& Wetherby, A.M. (1986). Communicative Intent: A framework for understanding social-communicative behaviour in Autism. American Academy of Child and Adolescent Psychiatry.

Su, Y., Naigles, L. R., \& Su, L. (2018). Uneven expressive language development in Mandarinexposed preschool children with ASD: Comparing vocabulary, grammar, and the decontextualized use of language via the PCDI-Toddler form. J Autism Development Disorder 48, 3432-3448 (2018).

https://doi.org/10.1007/s10803-018-3614-x

Amirrudin, S., \& Abd Rahim, N. (2019). Social Stories in the development of social 
competence and communication skills in the Autism Spectrum Disorder (ASD) child. IUKL Research Journal Vol. 7 No.1 2019

Wendt, O., Hsu, N., Simon, K., Dienhart, A., \& Cain, L. (2019). Effects of an iPad-based SpeechGenerating Device Infused into Instruction with the Picture Exchange Communication System for Adolescents and Young Adults with Severe Autism Spectrum Disorder. Behavior Modification 2019, Vol. 43(6) 898-932 